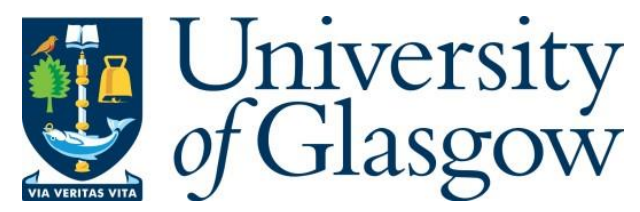

Mainwaring, $\dot{\mathrm{C}}$., and Brigden, N. (2016) Beyond the border: clandestine migration journeys. Geopolitics, 21(2), pp. 243-262.

There may be differences between this version and the published version. You are advised to consult the publisher's version if you wish to cite from it.

http://eprints.gla.ac.uk/140025/

Deposited on: 24 April 2017

Enlighten - Research publications by members of the University of Glasgow http://eprints.gla.ac.uk 


\title{
Beyond the Border: Clandestine Migration Journeys
}

\author{
Cetta Mainwaring \& Noelle Brigden
}

Introduction to Special Issue in Geopolitics, 2016, 21(2): 243-262. 
The world has turned its attention to the long and dangerous journeys undertaken by migrants. ${ }^{1}$ Not a week goes by without media reports of migrant boats capsizing in the Mediterranean and corpses washing ashore; of the tens of thousands of Middle-Eastern and African migrants who trek across the Balkans or Turkey to reach the European Union (EU); on the other side of the globe, of Asian trafficking and smuggling networks that span multiple countries or even continents; of people dying in hidden compartments in trucks or transport containers; or of the deteriorating human rights situation confronting Central Americans crossing Mexico to arrive in the US.

Some observers have argued that the recent intensified suffering along transnational migration routes that crisscross the globe constitutes the worst migration crisis since the end of World War II. Indeed, the number of people displaced due to war, conflict and poverty around the world has reached an all time high of 60 million. $^{2}$ Although western governments are quick to exploit and even encourage notions of crisis, disorder and chaos to justify deterrent migration policies, ${ }^{3}$ this humanitarian catastrophe is not isolated at the borders of the global north. It reaches along global migration routes around the world, stretching from communities in migrants' countries of origin, through transit corridors and into the communities intended to be their destinations. Migrants arriving at the borders of the US and EU have had the good fortune to survive an arduous journey across many countries to arrive at the doorstep of the global north.

Despite recent moral outcry over the suffering endured by migrants in transit, much of the academic scholarship on the geopolitics of migration focuses on the border as a site of control and resistance, as well as on migrant experiences in countries of destination. There are, of course, important exceptions. ${ }^{4} \mathrm{~A}$ burgeoning literature on 
'transit' migration engages, at least implicitly, with the journey. ${ }^{5}$ This literature has produced important insights into the fragmented nature of journeys and the politicization of the term 'transit'. Finally, a handful of imminent journalists and popular non-fiction writers have authored sustained explorations of these transnational journeys to borders, not just across them. ${ }^{6}$ However, we still lack systematic comparative scholarship that situates these multinational journeys in a global political context.

Building on these analytical beginnings, we turn our attention to how migrants arrive at the border, to the vehicles, networks, multiple border crossings and hardships that constitute the journey to the borders of developed countries. The collective contribution of this special issue is to move beyond the journeys of particular groups such as refugees, as well beyond particular country case studies, to provide a theoretically grounded and comparative analysis of clandestine migrant journeys. To do so, the special issue brings together scholars from across many disciplines to produce a unique comparative analysis of clandestine migration journeys into North America and Europe, with many of the articles drawing on rich ethnographic data.

We conceive 'the journey' broadly. The journey, as an experience with indeterminate beginnings and ends, transcends easy conceptual borders, as well as physical ones. Thus, for us, the concept encompasses imagined journeys before migration, journeys from countries of origin through countries of transit to destination, as well as deportation journeys. ${ }^{7}$ Centered around this broad idea of the journey, the empirical investigations within this volume reveal geographies of power, destabilize traditional concepts of transit and settlement, and disprove the ubiquitous political discourse that conflates trafficking and smuggling. They also challenge the 
oversimplified portrayal of smugglers as highly-organized criminals and migrants as victims with little or no agency.

As migration controls become increasingly restrictive and humanitarian crises erupt along clandestine migration routes, the special issue is a timely intervention that analyses how geopolitics shape and animate the everyday experiences of clandestine migration journeys. State bordering practices within and beyond their territorial boundaries encourage migrants to attempt clandestine journeys and contribute to the barriers they face along the route. Migrants on the losing end of the hierarchy of global citizenship are unable to access formal migration channels due to visa policies and other restrictions. ${ }^{8}$ These migrants must therefore traverse longer, more dangerous routes, often with the aid of smugglers. Migrants undertake transnational clandestine journeys both despite state bordering practices, and because of state bordering practices. Indeed, as a whole, the articles reveal that across these different geographies, migration controls extend beyond the edges of Europe and North America along routes, where migrants face increased danger, violence and risks during their journeys.

However, by examining the everyday practices involved in clandestine journeys, the authors of this special issue also demonstrate how migrants engage with the multiple geographies they travel across, find spaces within and between state practices of securitization, and ultimately constitute the geopolitics of migration. From marginalized positions, migrants continue to negotiate and maneuver, exhibiting a degree of agency reflected in successful journeys despite barriers. Even when migrants fail to reach their destinations, they transform the routes through countries of transit, engendering new relationships between foreigners and citizens along the way. Thus, taken together, these 
articles explore the global implications of clandestine journeys, demonstrating their challenge to state power, borders, and, ultimately, our understanding of 'security'.

In this short introduction, we argue that clandestine journeys merit systematic, comparative analysis. To do so, we bring together work from across regions, describing the journey's place in diverse migrants' lives. We position these experiences within the broader local, national, regional and global politics of the journey. As a thematic device, an analysis of the journey brings us to a deeper understanding of the links between that lived experience and the politics of migration. This analysis destabilizes the dichotomies that often structure our thinking about migration. First, we briefly introduce clandestinity and ambiguity as key concepts for understanding the contemporary migration experience.

Second, we situate these clandestine journeys in the academic literature on migration and within political discourse in order to demonstrate important struggles over conceptualizations of the journey. Third, we acknowledge the methodological challenges faced by scholars tracing the footfall of migrants, sometimes across many countries and legal statuses. Fourth, we summarize the contributions to the volume, locating this discussion in a global political context and highlighting the three broad themes that arise from the collection: (1) agency, (2) narratives and identity, and (3) uncertainty and violence. We conclude our summary with a call for further research, moving beyond the border to understand these global routes from a cross-regional perspective.

\section{Understanding ambiguity and clandestinity}

Journeys are both ambiguous and clandestine. Sometimes the beginning of a journey is not clear. Many migrants can cite a particular date when they crossed the threshold of their home, leaving behind the familiar to venture forth. However, that first 
step of the journey can also be understood as a continuation of a much longer life trajectory. Migrants sometimes understand the journey as embedded in this larger chain of events, and these events determine important aspects of how they travel, where they go and why. Determining the beginning of a journey becomes even more complicated when migrants change their destinations midstream, adjusting to unforeseeable events encountered en route. When does one journey end and another begin? Furthermore, migrants often make multiple attempts to arrive at their destination. Overtime these attempts constitute a traveling life, a continuous journeying without clear beginning or end.

Similarly, arrival is seldom clear for migrants who live under conditions of questionable legality, such as those that enter or stay under undocumented, irregular, illegal, or fraudulent pretenses. The ever-present threat of detection and deportation presents the immanent possibility of future journeys of return, and creates a lived space of liminality in which a sense of settlement cannot be achieved. ${ }^{9}$

This ambiguity is compounded by the fact that the (il)legality of particular practices is not always clear. Migrants traverse diverse legal environments and legal statuses in the course of a journey. The fluidity of migrant legal status in receiving countries is well documented, ${ }^{10}$ as is the ways in which migration controls create illegality. ${ }^{11}$ The diverse legal and physical geographies navigated en route increase the likelihood that some part of the journey is made in a clandestine manner. Thus, journeys comprise ambiguous temporal and legal dimensions.

In part a reflection of the complexity of the relationship between the migrant and the state, the authors in this special issue have chosen different terms to describe migrant 
status (irregular, undocumented, etc.). To analytically account for the temporal and legal ambiguity of journeys, we highlight the clandestinity that underpins this status, whatever the chosen terminology. Following Coutin, we define clandestine as 'a hidden, yet known, dimension of social reality. ${ }^{12}$ Human smuggling and migration routes are sustained practices, leaving visible traces in the physical, social, economic and political landscape of transit communities. As such, migrant journeys become common knowledge, despite migrants' often precarious legal status.

At the level of lived experience, clandestine journeys along these established routes become both routine undertakings, but also violent and unprecedented ruptures in the lives of migrants. By using the term clandestine, we hope to highlight these contradictions. In other words, we draw attention to the paradox of the visible (though often prohibited) smuggling and migration practices and a vulnerable population rendered invisible to some legal protections. Regardless of the adjective chosen by individual authors to describe migrant status, all the contributions to this volume recognize the ambiguous and fluid nature of (il)legality. Furthermore, each contribution explores this paradox of clandestinity across different regions and diverse legal, cultural and social contexts.

The distinction between refugees and labor migrants is contested politically, conceptually, legally, and in practice. Motives for migration are complex, and a person may cross these categories depending on the legal environment and their capacity to advocate for themselves. The migrant journey is likewise open to many interpretations. Migrants may be spurred simultaneously by individual aspirations and structural forces. Their motivations may include a complex interplay of hope for a better life, desire to join 
family and friends elsewhere, thirst for adventure, and fear of physical, social and economic forms of violence. Indeed, migration is more often than not encouraged by a multitude of such factors. Thus, recognizing the fluidity of migrants' status, we use the term 'migrants' to include both refugees and labor migrants.

\section{Conceptualizing the journey}

Policymakers, politicians, the media and even many academics continue to portray migrant journeys as direct passages between countries of origin and destination, represented by straight arrows on a map linking two distinct areas. In this depiction, journeys are less significant than factors that initiate migration and issues associated with settlement and integration. Here, we understand the journey to be as complex and significant as other phases of migration, and to have important implications for these other phases. We also argue that the migratory route is as complex and significant as other locations of migration research, such as origin and destination. The journey is not simply a space in between arrival and departure, a temporary moment of mobility between more 'normal' static existences, but a social process that shapes migrants and societies alike.

Furthermore, the journey has far-reaching consequences. It affects migrants' worldviews, attitudes, and even their bodies. As an experience, it potentially traumatizes or empowers them. The journey leaves physical, emotional and psychological traces on its survivors, following them in countries of destination, and on their communities back 'home'.

The physical trials required for passage also leave imprints on the landscape that migrants traverse. ${ }^{13}$ Footpaths form along the routes through the wilderness, marked by 
trails of trash and sometimes corpses. ${ }^{14}$ A political economy of transit emerges in the migration corridor, as shopkeepers and food vendors tailor their services and wares to the needs of a transient population. Archipelagos of motels, smugglers' drop houses, and humanitarian shelters link migration corridors, providing respite for weary travellers.

Journeys often traverse various physical geographies: land and sea, desert and forest. A single journey is very rarely linear or premeditated in its entirety. As migration controls have proliferated along and beyond borders, journeys have grown longer, both spatially and temporally. They are more circuitous, and more dangerous. These 'fragmented journeys' increasingly involve long periods of waiting or settlement interspersed with short bursts of mobility. ${ }^{15}$ Moreover, shrinking spaces of asylum and increasing restrictions on mobility cause migrant journeys to continue even once they 'arrive' in the global north. ${ }^{16}$

The conceptualization of migrant journeys is a political act. Representations of unceasing and linear migration flows reflect a politics of invasion and a moral panic around migration. At the same time, such representations actively co-construct these politics and panics. ${ }^{17}$ For example, Frontex, the EU's border agency, depicts migrant journeys as unidimensional and unidirectional lines or routes bound toward the EU. ${ }^{18}$ These representations are ahistorical, decontextualized, and thus depoliticized: they obscure imperial legacies, contemporary wars and economic inequalities that structure journeys and the routes that migrants travel. Indeed, such cartographic representations obscure social relations inscribed in space as well as more complex landscapes of mobility that include multidirectional flows of goods, capital investment, people, ideas, 
and images. Out of context, migrant journeys become an autonomous and unstoppable force that is easily securitized. ${ }^{19}$

There are of course important challenges to these representations. Activists, artists academics, and even migrants themselves, are increasingly engaging in acts of countermapping. ${ }^{20}$ Maps, exhibitions, videos, and other technologies produce alternative representations of journeys, migration flows, borders, migration controls, resistance and protest.

For example, Migreurop has produced many maps that represent complex migration systems, as well as EU migration controls, the spread of immigration detention centres in and around Europe, and migrant deaths along and within the EU's borders. ${ }^{21}$ Similarly, Hackitectura created a radical cartography of the Straits of Gibraltar, inverting traditional representations by placing Morocco at the top of the page and Spain at the bottom, and uncovering 'the multiple processes, regimes and agendas which co-exist, converge and clash at the space of the Straits - questions of work, territory, citizenship, technology, frontier controls, mobility, and much else'. ${ }^{22}$ More recently, Forensic Architecture reconstructed a fatal journey in the Mediterranean in 2011 and revealed how the 'Left-to-Die Boat' was not rescued despite the presence of many military vessels, aircrafts and other actors in the Central Mediterranean as part of the NATO-led intervention in Libya, and despite the distress signals sent by migrants on board. Using surveillance technology, Forensic Architecture's video report, Liquid Traces, as well their written report, maps how state actors evaded their legal responsibilities to rescue at sea and contributed to the deaths of 63 people on board the boat. ${ }^{23}$ 
On the other side of the Atlantic, Catholic shelters share maps of the journey marked with locations of resources and potential dangers with Central American migrants crossing Mexico to arrive in the United States. Over fifty of these Catholic shelters offer humanitarian support (food, water, shelter, etc.) to migrants in transit across Mexico, but some of the shelters also engage the politics of migration more directly by planning protests and documenting human rights violations. Beyond navigation, the maps they share also serve as political symbols to educate the public about the lived experience of migration. ${ }^{24}$ Further north, Humane Borders, in partnership with the Pima County Office of the Medical Examiner, produces and disseminates maps of migrant deaths at the U.S.Mexico boundary. ${ }^{25}$ The activist group Latino Rebels, partnered with United We Dream, is attempting to map the recent surge in immigration raids across the United States. ${ }^{26}$ This project, named MigraMap, calls upon witnesses to report the zip code of the raid, date, and whether the raid resulted in removal, as well as to explain how they came to know about the event.

Other images and narratives also challenge oversimplified and depoliticized interpretations of migrant journeys. The contested representation of migrant journeys continues over time as they are (re)imagined in dynamic and divergent ways by diasporas and host societies. For instance, BenEzer analyzes how 20,000 Ethiopian Jews who journeyed to Israel between 1977 and 1985 constructed narratives about their journey, and in doing so their identity: they saw the journey as demonstrating their strength and bravery, as well as their commitment to their Jewish identity. Due to the hardships they encountered in Ethiopia and en route, they also saw themselves as victims who had earned a right to become part of Israeli society. These narratives diverged from Israeli 
society's understandings of their journey and settlement, which raised doubts about their Jewish identity while also dismissing their Ethiopian identity, attributed their arrival to Mossad, the Israeli security service, and did not acknowledge the suffering they experienced during the journey. ${ }^{27}$ Similarly, despite recurrent (and often outlandish) xenophobia and anti-immigrant rhetoric, the 'Coming to America' narrative of overcoming hardship to arrive and survive in a New World, remaking oneself as well as a nation, has attained the status of a cliché in American political discourse. Moreover, this impact of collective imaginings of journeys and arrivals on national identities is not limited to traditional countries of immigration. In his historical study, The Battle of Britishness, Tony Kushner explores the politics of memory in representing migrant journeys and how these journeys help to construct British identity. ${ }^{28} \mathrm{He}$ argues that ' $[\mathrm{t}] \mathrm{he}$ migrant journey, real or imagined, has evoked especially strong, if often contradictory responses from state and public alike. Such responses have cut across politics and society and have been made manifest through varied representations from "self" and "other" and across many different cultural forms ${ }^{2}{ }^{29}$

The political significance of and contestation over journeys has a long history. Stories of the forced journeys made by Africans in the cross-Atlantic slave trade, and the ships that transported them, became potent symbols in the British anti-slavery movement. ${ }^{30}$ More recently, an activist-artist appropriated a visual representation of the slave ship the Brooks, an image that spurred public debate about the treatment of enslaved Africans in the $19^{\text {th }}$ century. This artwork superimposes the original drawing of slaves captive within the ship onto the image of an airplane. In so doing, it challenges the treatment of deportees from the United Kingdom. ${ }^{31}$ The mode and method of transport 
during a journey matters economically, socially and politically to migrants and nonmigrants alike.

Not surprisingly, given the salience of such imagery, the journey lingers both in the psyche of individual migrants and the collective imagination of receiving and sending societies. For individuals, the traumas endured can leave traces on bodies and in nightmares. Meanwhile, as William Walters points out, some migrants continue to be marked discursively - as wetbacks, boatpeople, stowaways, and clandestinos - by their crossings and particular modes of travel and transportation long after they have arrived. ${ }^{32}$

\section{Studying the Journey}

More sustained attention to migration journeys could continue to counter the limitations of traditional representations of migration flows by revealing trajectories that are non-linear, circular, seasonal, multi-directional, repetitive, and ambiguous. The study of journeys also undoes an entrenched bias in the discipline; migration studies tend to focus on 'successful' migrants who arrive in the global north, while overlooking those whose journeys are stymied. The journey offers a lens through which to explore the experiences and political impact of mobile populations who wander without arrival. As migration policing intensifies and a smaller percentage of migrants settle in their intended destination, the fate of this mobile, transient population has a growing importance in global politics. The study of journeys in which migration trajectories remain undetermined and uncertain allows us to think critically about the political, economic, social and personal consequences of non-arrival, arrival, and the spaces in-between 'successful' and 'failed' migration. 
Despite the advantages of studying migrant journeys, their long, fragmented, and clandestine nature presents methodological and ethical challenges and necessitates longitudinal studies. ${ }^{33}$ The unpredictability of beginnings and ends, as well as starts and stops within a journey, complicates the study of a mobile population. Journeys may be traced to different initiation points in a lifetime or even across generations. On the one hand, journeys can be understood as short affairs, making them difficult to witness, such as an airplane ride or a bus journey across a border. On the other hand, the clandestine migration journey may be understood as a protracted process, unfolding across time and space. The protracted nature of this process makes it equally difficult to capture by the academic parachuting in to conduct interviews during brief spells of fieldwork.

Given these challenges, it is unsurprising that academics employing ethnographic methods have given the most sustained attention to the migrant journey. ${ }^{34}$ Others have used narrative approaches to access retrospective viewpoints on the journey. ${ }^{35}$ However, even here there are limitations: clandestine journeys are often punctuated with long moments of immobility that blur the sharp edges drawn by academics and policymakers to demarcate the beginning and end of the migration process. ${ }^{36}$ Furthermore, after arrival, 'settled' migrants may leave their 'destination' in the face of new opportunities or hardship, unexpectedly continuing their journey. Indeed, the need to talk of journeys as discrete moments is born from methodological necessity, and to some extent, potentially arbitrary decisions by researchers, not a preexisting logic of migration.

The lack of attention given to migrant journeys also reflects our methodological nationalism. ${ }^{37}$ In an imagined Westphalian world, these journeys fall between or outside of states in many ways, especially if they are clandestine. Nevertheless, despite the 
limited attention given to migrant journeys, they are significant in understanding the lengths migrants go to in order to reach the first world, and the ways in which policies in countries of origin, transit and destination encourage, interrupt, and shape these journeys.

Studying the journey also raises ethical questions and challenges. Some of these apply to studying vulnerable migrant populations in general. ${ }^{38}$ However, researching the journey can also present its own unique ethical challenges. The presence of researchers along the route can draw attention to those undertaking clandestine journeys, who may wish to remain hidden. Publishing details about migrant routes and strategies may result in routes being further policed and made unavailable to travellers. Moreover, given the violence often experienced along the route, the possible trauma involved in recounting experiences of the journey must be considered. Finally, Jason de Leon reminds us that participant observation during migrant journeys must avoid a voyeurism that characterizes travel literature, which centers on the experience of the author rather than the migrant. ${ }^{39}$

In this brief introduction, we do not have the space to adequately address these ethical issues and challenges. Nor do we claim to have the answers to these difficult questions. Indeed, we would argue against framing the discussion in terms of right and wrong approaches. Nevertheless, we raise these ethical concerns as a vitally important element of conducting research on migrant populations in general and migrant journeys in particular. In summary, researching and writing about migrant journeys requires reflexivity, humility and caution. 


\section{Overview of this special issue}

Facing these challenges, many of the authors in this special issue investigate journeys from multiple positions along the route, moving between countries of origin, transit, or destination. Many have employed ethnographic methods, including participant observation. As a transnational social field knit together by this process, migration corridors, encompassing the geography of origin, transit, detention, deportation and destination, become the natural field site to study journeys.

In this special issue, the exploration of this transnational social field is divided into three sections. The first two sections analyze journeys into Europe (see Innes, Kayztaz, and Ustubici this issue) and the United States (see Soto, Stone-Cadena, Vogt, and Sanchez this issue), respectively. The last section includes two papers that draw together themes and geographic regions: one examines the practices and material spaces of journeys, with a particular focus on deportations (see Williams this issue); the other provides a more direct comparative analysis of journeys into Europe and the United States (see Brigden \& Mainwaring this issue). The articles throughout the special issue draw on intensive fieldwork from around the globe. In so doing, they generate a crossregional dialogue about the role of agency, narratives and identities, and uncertainty and violence during smuggling and migration. Collectively, they demonstrate how the study of migration journeys and transit corridors contributes to our understanding of the geopolitics of migration beyond borders.

\section{Part 1: Journeys to the European Union}

Alexandria Innes explores a performative conceptualization of security through the narrative of a Ghanaian asylum seeker in Greece, Sonny. Drawing on Sonny's 
narrative about his experience of the journey to Greece, Innes eloquently argues in favor of conceptualizing security as practice and everyday experience, rather than an object to be obtained. Analyzing security and agency within the context of the migrant journey allows Innes to move beyond the nation-state, a concept that has limited traditional analyses within security studies and international relations more broadly.

Similarly, with an analysis of migrants' narratives about their journeys, Esra Kaytaz examines the non-linear journeys of Afghans to Turkey. Drawing on rich ethnographic data, she illustrates how migrants negotiate and understand uncertainty and long periods of immobility during the journey. Kaytaz argues that migrants' construction of a narrative about the journey gives meaning to the process of mobility and reflects a degree of migrant agency.

Continuing to explore expressions of migrant agency, Aysen Ustubici considers how clandestine migrant journeys to Europe can give rise to political activism even in countries of 'transit'. Having carried out fieldwork in Morocco between 2012 and 2014, Ustubici analyses how migrants forge alliances with local and transnational actors and frame their demands within local and transnational contexts in order to make claims to human rights. In Morocco, the activism of migrants, so often depicted as 'in transit', has encouraged the regularisation scheme implemented by the government in 2014. Thus, Ustubici uncovers a political space beyond transit forged by migrant activism. While migrant narratives may represent a vehicle for migrant empowerment, state narratives of 'transit' obscure this migrant agency.

These contributions to our understanding of journeys to the European Union artfully uncover a relationship between narrative, meaning-making and migrant agency 
en route. Migrants draw on symbolic resources, both intentionally and unintentionally, as they cope with the extreme uncertainty and risk produced by bordering practices. In so doing, they challenge state-centric understandings of 'security'.

\section{Part II: Journeys to the United States}

Contributions that explore the journey in the Americas build on the themes of migrant narratives, meaning-making and agency in the face of extraordinary uncertainty and violence. First, Lilia Soto's article explores how Mexican teenage girls imagine the journey northward before departure and after arrival. Drawing on the experiences of three Mexican teenage girls in Napa, California, she analyses the importance of the 'telling moment' when they were informed of their imminent departure from their home. Soto illustrates how their age and gender circumscribe their influence in the decision-making process, but how they nevertheless negotiate and prepare for departure both physically and emotionally. Focusing on this moment of transition, filled with uncertainty and turmoil, Soto provides a novel perspective on the journey as it is (re)imagined. In this way, Soto shows how even some of the most disempowered migrants, in this case young girls, find an active role in shaping their destiny. They achieve this agency through the narratives of journeying they re-imagine around the 'telling moment'.

Victoria Stone-Cadena reveals another potential source of migrant agency and meaning-making: ethnic solidarity. However, she also probes the limits of this collective empowerment. To do so, she turns our attention to migration from Ecuador to the United States and in particular to the experiences of indigenous Cañari migrants and migration merchants from the southern highlands of Ecuador. To better understand the role of ethnicity in patterns of smuggling and violence, Stone-Cadena discusses the extent to 
which ethnic solidarity among indigenous migrants from Central America influences their journeys. She argues that although indigenous identity may be used strategically to forge new transnational social networks, Cañari migrants and migration merchants also experience marginalization due to ethnic and linguistic discrimination. The collective empowerment of migrants remains incomplete in the face of such structural constraints.

Returning to the special plight of female migrants, Wendy Vogt also focuses on the interplay between identities and smuggling. However, she draws our attention to the Central Americans crossing Mexico. Inspired by transnational feminist scholarship and drawing on her own ethnographic research, she innovatively re-conceptualizes smuggling as a form of intimate labor, informed by traditional gender roles, along migrant routes. Although migrants experience violence and insecurity during transit, they also engage in intimate economies of exchange, kinship and care en route. Vogt pushes us to move beyond traditional understandings of smuggling as inherently exploitative, while still analyzing how smuggling can contribute to new forms of inequality.

In a continued exploration of how gender affects patterns of smuggling and violence, Gabriella Sanchez examines the special role of female smugglers in the USMexico borderlands. Like Vogt, Sanchez contributes an important perspective to the limited empirical research on human smuggling. Sanchez challenges conventional accounts that focus on the oversimplified figure of the exploitative and violent male smuggler. She draws on court transcripts and interviews conducted with female facilitators to demonstrate the active and varying roles they play along clandestine journeys, disrupting the narrative of routes controlled by unsavory, male criminals, and of women as passive victims in the smuggling process. In contrast, Sanchez argues that 
smuggling can be understood as a legitimate form of labor and practice in community formation, and that it lies along a continuum of forms of resistance to notions of labor, crime, and illegality imposed by the state and the neoliberal economic order.

Taken together, these contributions from the Americas emphasize how gender and ethnic identities underpin both positive and negative experiences of the journey. The capacity of migrants to confront, resist and subvert state bordering practices comes into view as we take narratives of the self and the journey seriously. However, these contributions also highlight the extraordinary uncertainty and violence that journeys entail. The authors in this special edition clearly attribute this uncertainty and risk, experienced by migrants as danger and suffering, to the transnational character and intensification of border policing across the region.

\section{Part III: Comparisons and state responses}

The initial two sections of the special issue outlined above deliver rich comparisons between case studies carried out on journeys to the European Union and journeys to the United States. The final section provides a more direct comparative analysis of journeys to these two areas of the global north, as well as an analysis of deportation journeys and the modes of transportation implicated in this state-enforced movement of populations.

In our contribution (see Brigden and Mainwaring this issue), we compare the experiences of migrants en route to the United States and to the European Union. Our article illustrates how immobility is an inherent part of these fragmented journeys, especially as states increase controls at and beyond their borders. By bringing together fieldwork from two continents, North America and Southern Europe, we demonstrate 
how policing, justified by language of crisis and rescue, ruptures journeys. Drawing on the analogy of a matryoshka, a nested series of dolls, we argue that, likewise, migration journeys become a nested series of adventures and concealment strategies, as migrants attempt to evade capture by the state or escape criminal predators. These 'matryoshka journeys' reveal how increased migration controls encourage them not only to take greater risks during the journey, but also to forfeit their agency at opportune moments. In turn, states exploit images of such im/mobility during the journey to emphasize the seemingly irrational risks migrants take in traversing seas and deserts. In this way, states cloak their own border policies in a humanitarian discourse of rescue.

William Walters calls attention to the importance of practices and spaces of transportation during the migrant journey - and their relative neglect in migration and border studies. Indeed, Kushner also contends that ' $[t]$ he details of physical journeys and modes of transport are particularly subject to amnesia and oblivion...' ${ }^{40}$ Examining the vehicles implicated in deportation by air from the UK, Williams brings to the fore a journey that has been relatively overlooked in scholarship. His analysis illustrates the techniques and tactics that turn commercial and charter flights into sites of deportation, and how these material places are zones of knowledge, tactics, and politics. His contribution reveals how the airplane, as a site of deportation, is not only a mechanism through which policy is enacted but also a site of struggle and violence that shapes deportation practices and policies.

Studying migration journeys in this comparative manner makes visible social relationships, societal changes and human experiences that situate migration within 
broader social, political, and economic contexts. Here, we make particular note of just three themes that emerge: agency, narratives and identity, and uncertainty and violence.

\section{Agency}

Taken together, these articles forcefully demonstrate migrants' roles in shaping their own destiny. Despite grave threats to their safety and extreme hardships endured, migrants do not passively accept the course of their journey. They do not surrender full control to their smugglers, the state or their circumstances, but instead leverage ingenious tactics to facilitate their mobility. Kaytaz's vivid discussion of Afghan migrants reveals social skills and networks acquired during the journey. Thus, the route can become a transformative space in which migrants realize their potential. For Ustubici, migrants acquire social resources for survival, as well as skills for political engagement.

Furthermore, the contributions of this volume not only demonstrate the agency of the most privileged or proactive migrants, but also surprising moments of selfempowerment experienced by populations traditionally considered among the most vulnerable of migrants, such as women and children. Soto shows us how a group of teenage girls shape their journeys, despite having many decisions made for them. Vogt discusses female migrants' vital, though exploited, provision of intimate labor during the journey. While Vogt tells the story of exploited female migrants, Sanchez highlights the role of female smugglers in facilitating the mobility of others around them, while sometimes making a profit. Migrant agency is not limited to the realm of men.

Finally, in our contribution, we explore the layers of migrant empowerment and disempowerment that unfold during the stopping, waiting, detention, containment and captivity during the journey. Even under the most extraordinary conditions of immobility, 
such as when migrants find themselves locked in hidden compartments or trapped on unseaworthy vessels, we see a relationship between the temporary surrender of agency and a larger strategy to achieve the goal of mobility and, with luck, a more permanent empowerment at their destination. Like Kaytaz, we show the complex negotiations through which migrants engage both state actors and smugglers. For Innes, a true recognition of this migrant agency calls for a rethinking of the very concept of 'security': one that refocuses our attention on the needs of marginalized people as well as the resources and strategies these people utilize to provision for their own security.

\section{Meanings: Narratives and identities}

As a collective, these articles also teach us that the journey is fundamentally a meaning-making process, imbued with symbolic significance. Migrant narratives are a resource for researchers seeking to understand the experience of the journey, but the narratives of migrants' identities and experiences of the journey are also a resource for migrants themselves. ${ }^{41}$ Innes demonstrates how using an asylum seeker's narrative about the journey reveals his agency in navigating obstacles en route, as well as how he identifies sources of insecurity. Moreover, it allows her to conceptualize security as a process that Sonny negotiates, performs, and produces. It is 'the action taken to obtain security - the process of security - that constitutes security for Sonny as opposed to the object that he might or might not obtain.'

Similarly, Kaytaz deftly demonstrates how the process of constructing narratives is an 'agentic action' that 'imbues the journey with meaning and constitutes the presence'. It is a skill that is necessary in many immigration processes, from asylum procedures to confrontations with border guards and immigration officials at borders 
crossings. The construction and recounting of a narrative about the journey simultaneously constructs a traveller's individual and group identity: for instance, Kaytaz's informants point to the bravery and resolve of Afghans to explain their ability to survive hardships and danger along the route.

The contributions of Stone-Cadena, Vogt and Sanchez show how migrantsmuggler contracts and their ongoing re-negotiation during the migrant journey depend on ethnic and gender identities. Such identities become surprising resources for forging new relationships and contracts under uncertain and risky social conditions. ${ }^{42}$ However, such identities also produce patterns of vulnerabilities for migrants in passage. Vogt illustrates the dark side of gendered smuggling practices, highlighting the exceptional exploitation and violence experienced by female migrants. Stone-Cadena, while arguing that indigenous solidarity may provide the basis for transnational social networks, also acknowledges continued ethnic and linguistic barriers that may render indigenous migrants vulnerable to abuse. Thus, we come to understand a fluid relationship between journeys and identities, each with the power to shape the other.

\section{Uncertainty \& violence}

This collection does not just tell a story of migrant agency, however. It also highlights the suffering and sacrifice the journey entails. All the contributions include stories of pain, fear, longing, forced captivity and even death. Moreover, they reveal how forms of violence en route are racialized, gendered, and classed. An inescapable fact emerges from research across these geographical regions: increased migration policing exacerbates the experience of uncertainty and violence along clandestine routes. 
Intensifying migration controls and unevenly circumscribed opportunities for cross-national mobility narrow the travel options available to much of the world's population. In a context of gross global inequalities and continued economic and political instability in the global south, these restrictions necessitate reliance on smugglers, thereby increasing the likelihood of exploitation, abuse, rape, dismemberment and death suffered en route. The ambiguous, clandestine routes that emerge in the wake of such policies and violent practices heighten the uncertainty experienced by migrants. Elsewhere, Vogt argues that the everyday acts of violence experienced during journeys across Mexico arise 'at the intersection between local and global economies that profit from human mobility' and are embedded within logics of global capitalism and state militarism. ${ }^{43}$ Indeed, the contributors to this special issue reveal how journeys become longer, more uncertain, and more dangerous in the face of increasing state migration controls. They also demonstrate how fellow migrants, smugglers, and private security personnel also perpetuate this state violence.

For instance, Walters draws our attention to the political economy of violence that underpins deportation journeys. Commercial airlines and private security actors are implicated alongside the state in strategies and techniques that obscure the inherent violence of forced removal. On the deportation flight, violence is reconceived as 'techniques of restraint' and 'non-compliance management'. In this obfuscation of violence, commercial actors restrict the space for resistance to deportation policies.

Our contribution points to how states also employ a very different tactic of obscuring violence: an insincere humanitarian discourse that justifies the proliferation of migration controls. States in both Europe and the Americas are quick to point to the risks 
and violence endured by migrants to legitimate increased apprehension efforts. 'Saving migrants' from their captivity and victimization at the hands of smugglers becomes a rallying cry for the very policies that actually encourage more dangerous clandestine journeys. A thin veneer of humanitarianism masks and facilitates the reproduction of ineffective deterrent policies, the militarization of the border, and the diffusion of controls beyond the border. In this way, our collective contribution explores both migrants' agency and the political structures that constrain that agency.

\section{Blazing a Trail for Future Work on Journeys}

Understanding the journey nuances our understanding of danger encountered and successfully negotiated, while not discounting the violence and suffering confronted by migrants. Indeed, examining the journey reveals populations that die, are deported, or remain in limbo along migration routes across the global south. These transient populations remain hidden if we limit our analysis to the borders of the global north. Borders do not demarcate the end or beginning of these precarious journeys, which constitute dynamic socio-political processes in a transnational social field. In that process, migrants may experience a complex and ambiguous mix of empowerment and disempowerment. The contributions to this collection represent a first step in disentangling this complexity on a global scale.

Given the tremendous suffering caused by increased migration policing and the seriousness of this ongoing humanitarian catastrophe, scholars should approach the next step of this research agenda with great urgency. This special edition blazes a trail for future work on migrant journeys across regions and historical moments. We call on scholars to challenge narratives of the state with grounded empirical work alongside 
migrants at various points in their journey, and to collaborate to bring rich fieldwork into comparative perspective. This collection identifies key themes of agency, narratives and identity, and uncertainty and violence around which such comparisons may be structured. Understanding the lived experience of migration journeys in this way reveals the contours of a larger, and often intentionally obscured, global political economy of migration control.

Finally, the journey resonates across geographies, time, and cultures as an apt metaphor for the human condition. Of course, the enduring and universal allure of the journey should not be surprising. Human mobility is the great motor of human history. Not coincidentally, journeys are the greatest storytelling device: the motor of plots ranging from Biblical scriptures to contemporary popular films and novels. The symbolism of the journey motif is not lost on its storytellers. Across many cultures, pilgrimage, crusades, and walkabouts represent rites of passage. Journeying, in some sense, is synonymous with living, and when navigated successfully, becoming the master of your own destiny. For this reason, narratives of journeys hold a special place in our collective imagination, and structure our identity as peoples long after we have settled in one place. Further analyses of migrant journeys can thus teach us about the politics of migration and about humanity more broadly.

\footnotetext{
${ }^{1}$ We use the term 'migrants' broadly to denote people who move across international borders, including refugees, economic migrants, and others who do not fall neatly within these legal categories.

${ }^{2}$ UNHCR, 'Worldwide displacement hits all-time high as war and persecution increase', News Stories, (18 June 2015).

${ }^{3}$ C. Mainwaring, 'Constructing a Crisis: The Role of Immigration Detention in Malta', Population, Space and Place, 18 (2012) pp.687-700; A. Mountz and N. Hiemstra, 'Chaos and
} 
Crisis: Dissecting the Spatiotemporal Logics of Contemporary Migrations and State Practices', Annals of the Association of American Geographers, 104 (2014) pp.382-90.

${ }^{4}$ E.g. M. Collyer, 'Stranded Migrants and the Fragmented Journey', Journal of Refugee Studies 23/3 (2010) pp.273-93; G. BenEzer, The Ethiopian Jewish Exodus: Narratives of the Journey (London: Routledge 2004); G. BenEzer, and R. Zetter, 'Searching for Directions: Conceptual and Methodological Challenges in Researching Refugee Journeys', Journal of Refugee Studies 28/3 (2015) pp.297-318; S. Khosravi, 'Illegal' Traveller: An Auto-Ethnography of Borders (Basingstoke: Palgrave Macmillan 2011); T. Kushner, The Battle of Britishness: Migrant Journeys, 1685 to the Present (Manchester: Manchester University Press 2012).

5 M. Collyer, F. Düvell, and H. de Haas, 'Critical Approaches to Transit Migration', Population, Space and Place 18/4 (2012) pp.407-14; F. Düvell, 'Transit Migration: A Blurred and Politicised Concept', Population, Space and Place 18/4 (2012) pp.407-81.

${ }^{6}$ In recent years, the media has in many ways been at the forefront of attempts to depict the journey through articles that follow particular individuals or groups of migrants en route (e.g. 'Fear, fatigue and separation: a journey with migrants willing to risk everything', The Guardian, 6 April 2015; P. Kingsley, 'The Journey', The Guardian, 9 June 2015), as well as through more interactive pieces that ask readers to imagine making the choices that migrants face during a journey (e.g. 'Syrian Journey: Choose your own escape route', BBC, 1 April 2015; 'The refugee challenge: can you break into Fortress Europe?', The Guardian, January 2015). Popular nonfiction accounts include: P. Kenyon, I Am Justice: A Journey out of Africa (London: Preface Publishing, 2009); O. Martinez, The Beast: Riding The Rails And Dodging Narcos On The Migrant Trail (London: Verso 2014); C. Moorehead, Human Cargo A Journey among Refugees (London: Vintage Books 2005); S. Nazario, Enrique's Journey (New York: Random House 2007).

${ }^{7}$ Deportation or return journeys have received even less attention in the scholarly literature. Notable exceptions include contributions to the following edited volume: N. De Genova \& N. Peutz (eds.), The Deportation Regime: Sovereignty, Space and the Freedom of Movement (Duke: Duke University Press 2010).

${ }^{8}$ Cf. S. Castles, 'Nation and Empire: Hierarchies of Citizenship in the New Global Order', International Politics 42/2 (2005) pp.203-24.

9 N. De Genova, 'Migrant "Illegality" and Deportability in Everyday Life', Annual Review of Anthropology 31 (2002) pp.419-47; M. Cook. "Is Incorporation of Unauthorized Migrants Possible? Inclusion and Contingency for Non-Status Migrants and Legal Immigrants', in J. Hochschild, J. Chattopadhyay, C. Gay, and M. Jones-Correa (eds.), Outsiders No More? Models of Immigrant Political Incorporation (New York: Oxford University Press 2013); C. Menjívar, 'Liminal Legality: Salvadoran and Guatemalan Immigrants' Lives in the United States', American Journal of Sociology 111/4 (2006) pp.999-1037; N. Sigona, "I Have Too Much Baggage": The Impacts of Legal Status on the Social Worlds of Irregular Migrants', Social Anthropology 20/1 (2012) pp.50-65.

${ }_{10}^{10}$ E.g. Menjívar (note 9).

${ }^{11}$ E.g. B. Anderson, N. Sharma, and C. Wright, 'Editorial: Why No Borders?', Refuge: Canada's Journal on Refugees 26/2 (2011) pp.5-18.

${ }^{12}$ S.B. Coutin, 'Being En Route', American Anthropologist 107/2 (2005), p.196

${ }^{13}$ N. Brigden, 'A Visible Geography of Invisible Journeys: Information, Representation and the Politics of Survival'. Unpublished manuscript, presented at Governing from the Margins, Balsillie School of International Affairs, Waterloo, Ontario, 2015.

${ }^{14}$ J. De Leon, 'Better Hot than Caught: Excavating the Conflicting Roles of Migrant Material Culture', American Anthropologist 114/3 (2012) pp.477-495; V. Squire, 'Desert "trash": 
Posthumanism, Border Struggles, and Humanitarian Politics', Political Geography 39/5 (2014)

pp.11-21.

${ }^{15}$ M. Collyer, 'Stranded Migrants and the Fragmented Journey', Journal of Refugee Studies 23/3 (2010) pp.273-93.

${ }^{16}$ A. J. Innes, 'The Never-Ending Journey? Exclusive Jurisdictions and Migrant Mobility in Europe', Journal of Contemporary European Studies 23/4 (2015) pp.500-513; A. Mountz, 'Where Asylum-Seekers Wait: Feminist Counter-Topographies of Sites between States', Gender, Place \& Culture 18/3 (2011) pp.381-99. L. Schuster, 'Turning Refugees into "illegal Migrants": Afghan Asylum Seekers in Europe', Ethnic and Racial Studies 34/8 (2011) pp.13921407; L. Schuster and N. Majidi, 'What Happens Post-Deportation? The Experience of Deported Afghans', Migration Studies 1/2 (2013) pp.221-40

${ }^{17}$ W. van Schendel, 'Spaces of Engagement: How Borderlands, Illegal Flows, \& Territorial States Interlock', in W. van Schendel and I. Abraham (eds.), Illicit Flows and Criminal Things: States, Borders, and the Other Side of Globalization (Bloomington: Indiana University Press 2005) pp.38-68; H. van Houtum, 'Human Blacklisting: The Global Apartheid of the EU's External Border Regime’ Environment and Planning D: Society and Space 28/6 (2010) pp.957-76.

${ }^{18}$ E.g. Frontex, Annual Risk Analysis (Warsaw, Poland: Frontex 2015) p.19. This is replicated on the migratory route map on their website: $\mathrm{http}$ ://frontex.europa.eu/trends-and-routes/migratoryroutes-map/; Conversely, the same Annual Risk Analysis depicts stolen (European) cars exiting the EU through similar routes (Ibid, p. 38). Frontex is not unique in its representation of migrant journeys in this manner: the EU, International Centre for Migration Policy Development (ICMPD), UNHCR, and others represent migrant journeys in these cartographic forms (e.g. Dialogue on Mediterranean Transit Migration, '2014 Map on Mixed Migration Routes', available here: http://www.imap-migration.org/fileadmin/Editor/Visualisations/MTM/iMap poster 14.05 ENGLISCH_Screen_reduced.pdf).

${ }^{19}$ W. Walters, "Anti-Political Economy: Cartographies of "Illegal Immigration" and the Displacement of the Economy', in J. Best and M. Paterson (eds.), Cultural Political Economy (London: Routledge 2009) pp.113-138.

${ }^{20}$ Brigden (note 13); M. Tazzioli, 'Which Europe?. Migrants' Uneven Geographies and CounterMapping at the Limits of Representation' Movements. Journal Für Kritische Migrations- Und Grenzregimeforschung 1/2 (2015); Walters, 'Anti-Political Economy' (note 19).

${ }^{21}$ Migreurop, Atlas des migrants en Europe. Géographie critique des politiques migratoires européenne (Paris: Armand Colin 2012), available here: http://www.migreurop.org/article2574.html?lang=fr

${ }^{22}$ Walters, 'Anti-Political Economy' (note 19) p.129; Hackitectura, Critical Cartography of Gibraltar (2014), available here: http://www.antiatlas.net/en/2013/09/08/hackitectura-criticalcartography-of-gibraltar-2004-spain/

${ }^{23}$ C. Heller, L. Pezzani and Situ Studio, 'Report on the "Left-To-Die Boat"' (2012). Available here: http://www.forensic-architecture.org/wp-content/uploads/2014/05/FO-report.pdf ; For video report see: http://www.forensic-architecture.org/case/left-die-boat/\#toggle-id-3

${ }^{24}$ Brigden (note 13).

${ }^{25} \mathrm{http}: / /$ www.humaneborders.info/

${ }^{26}$ Available here: https://migramap.latinorebels.com/map/

${ }^{27}$ BenEzer (note 4).

${ }^{28}$ Kushner (note 4).

${ }^{29}$ Ibid, p.4

${ }^{30}$ M. Rediker, The Slave Ship: A Human History (New York: Penguin Books 2007) pp.326-331. 
${ }^{31}$ P. Miller and S. Youssef. Collective Expulsion: The case against Britain's mass deportation charter flights (London: Corporate Watch 2013). Available here: https://corporatewatch.org/sites/default/files/Collective-Expulsion-report.pdf

${ }^{32}$ W. Walters, 'On the Road with Michel Foucault: Migration, Deportation and Viapolitics', in S. Fuggle, Y. Lanci, and M Tazzioli (eds.), Foucault and the History of Our Present (New York: Palgrave Macmillan 2015) pp.326-331.

${ }^{33} \mathrm{Cf}$. BenEzer and Zetter (note 4).

${ }^{34}$ Khosravi (note 4).

${ }^{35} \mathrm{Cf}$. BenEzer and Zetter (note 4) pp.16-17.

${ }^{36}$ Cf. S. Hess, 'De-Naturalising Transit Migration. Theory and Methods of an Ethnographic Regime Analysis', Population, Space and Place 18/4 (2012) pp.428-40.

${ }^{37}$ A. Wimmer and N. Glick Schiller, 'Methodological Nationalism and beyond: Nation-state Building, Migration and the Social Sciences', Global Networks 2/4 (2002) pp.301-34.

${ }^{38}$ F. Düvell, A. Triandafyllidou, and B. Vollmer, 'Ethical Issues in Irregular Migration Research in Europe', Population, Space and Place 16/3 (2010) pp.227-39; I. Van Liempt and V. Bilger (eds.), The Ethics of Migration Research Methodology: Dealing with Vulnerable Immigrants (Brighton: Sussex Academic Press, 2009).

${ }^{39}$ J. De Leon, The Land of Open Graves: Living and Dying on the Migrant Trail (Oakland: University of California Press 2015) pp.12-13.

${ }^{40}$ Kushner (note 4) p.73.

${ }^{41}$ On the performance of national identities as a migration resource during the journey, $\mathrm{N}$. Brigden, 'Improvised Transnationalism: Clandestine Migration at the Borders of Anthropology and International Relations', International Studies Quarterly (forthcoming).

${ }^{42}$ N. Brigden, 'Gender Mobility: Survival Plays and Performing Ethnography with Migrants in Passage', unpublished manuscript, presented at the Annual Meeting of the American Political Science Association, Chicago (2013).

${ }^{43}$ W. A. Vogt, 'Crossing Mexico: Structural Violence and the Commodification of Undocumented Central American Migrants', American Ethnologist 40/4 (2013) pp.764-65. 